\title{
Is the Halloween Effect Present on the Markets for Agricultural Commodities?
}

\author{
Dmitry Burakov', Max Freidin ${ }^{2}$ \\ ${ }^{1}$ Department of Financial Markets \& Banks, Financial University under the Government of Russian \\ Federation, Russia \\ ${ }^{2}$ Department of Marketing, Belarusian State Agricultural Academy, Belarus
}

\begin{abstract}
Seasonal anomalies play an important role in the global economic system. One of the most frequently empirically observed anomalies is the Halloween effect. Halloween effect describes the anomaly on the financial markets, which is that the returns of different assets in the summer period are generally lower than the returns in the winter period. This study tests the Halloween effect on the agricultural commodities' markets over the period from 1980 to 2016. The sample includes price series of 27 major agricultural commodities. The data show that 20 out of the 27 commodities recorded a higher average winter period than summer period returns and in 15 cases, the differences are statistically significant. The data also show that out of the 7 commodities with higher summer period returns (the "reverse Halloween effect") only in cases of poultry and tea the differences are of statistically significant nature.
\end{abstract}

\section{Keywords}

Halloween effect, financial market, agriculture, commodity, seasonal anomaly.

Burakov, D. and Freidin, M. (2018) "Is the Halloween Effect Present on the Markets for Agricultural Commodities?", AGRIS on-line Papers in Economics and Informatics, Vol. 10, No. 2, pp. 23-32. ISSN 1804-1930. DOI 10.7160/aol.2018.100203.

\section{Introduction}

\section{Seasonal anomalies: problem statement}

Financial markets are in constant evolution. Markets are constantly developing new methods of risk analysis. There are new products and technologies that contribute to increasing information asymmetry. But even against the desire of market players to reduce market uncertainty, force of habit as a manifestation of bounded rationality continues to exist. Among the manifestations of bounded rationality in the prevailing habits and traditions are seasonal or calendar anomalies. Calendar anomaly is a cyclic pattern of behavior of players of different markets, characterized by cyclical oscillations in returns in the financial markets. The most common seasonal anomalies are day of the week effect, January effect, the month effect and the Halloween effect. Studies show that not all the calendar anomalies occur in each market. Among the most common cases, the calendar effect is found in equity markets (Lakonishok and Smidt, 1988; Haggard et al., 2015), however some authors found that seasonal anomalies can be present on the markets of different goods (Milonas, 1991; Borowski, 2015).
Since seasonal and calendar anomalies represent irrational form of habits, it is logical to assume that the Halloween effect is in contradiction with the full rationality assumption of the neoclassical school of economic thought. In the case of financial markets, this contradiction is manifested in the inability to describe this seasonal anomaly with the efficient markets hypothesis (Fama, 1965). As follows from the main provisions of the efficient markets hypothesis, the current price of an asset incorporates and reflects all the available information about the asset, respectively, arbitrage opportunities or generating income above the norm on the market simply do not exist when using fundamental or technical analysis.

However, empirical observations and studies of many authors, described below, show the existence of data anomalies and confirm the possibility of obtaining abnormal returns, even taking into account transaction costs and adaptive expectations of market players.

\section{Literature review}

Halloween effect was first identified on the securities market. The basis of this seasonal anomaly is the assumption, according to which stock returns 
in the May-October period are significantly lower than in the second half of the year. For example, a study by Bouman et al. (2002) has shown that the Halloween effect is present in the securities markets of 36 developed and developing countries. Other studies confirmed the results of Bouman et al. (2002) and have shown that the Halloween effect exists for various stocks and for various segments of the market. For example, a study of Lean (2011) showed the presence of the Halloween effect in the stock markets of several Asian countries (Malaysia, China, India, Japan, Singapore). Jacobsen and Nuttawat (2009) found that 48 out of 49 U.S. sectors of the stock market showed better result in the winter period rather than in the summer period. For $2 / 3$ of the sectors, the difference was statistically significant. The study is based on time series sample from 1926 to 2006. Andrade et. al (2013) came to the conclusion that the Halloween effect not only affects the value of assets, but also on the credit risk premium and volatility. Zhang and Jacobson (2013) examined data on the securities market of Great Britain for a period of more than 300 years. As a result, the authors came to conclusion that calendar and seasonal effects took place, although their scope and importance has changed significantly. The Halloween effect was present constantly regardless of the applied methods.

Commodity markets and commodity prices are under close attention of researchers all over the world. Most of papers pay attention to either food price crisis (Etienne et al.. 2014; Hochman et al., 2014) or various factors affecting commodities' prices (Liu, 2014; Ott, 2013; Hamilton and Wu, 2015; Čermák et. al., 2017). Much attention is paid to the relation between agricultural commodities' prices and oil prices (Mensi et al., 2014; Wang et al., 2014; Burakov, 2017). Nevertheless, little attention is paid to the Halloween effect and different seasonal patterns concerning commodities markets, particularly markets for agricultural goods (Arendas, 2017).

Markets for agricultural commodities are specific not only due to the necessity of providing food security, but also due to high volatility on demand and supply sides. A sharp rise in demand for particular agricultural commodity may lead to a strong increase in market prices. And contrary - a sharp decline in supply (due to poor harvest or natural disaster/weather anomalies) would also lead to a strong rise in prices in the short run. Specifics of agricultural markets are strongly connected with production cycles, which may give birth to seasonal patterns in the market prices' dynamics. Agricultural markets may also be a subject to price volatility due to speculations on financial markets, which could lead to occurrence of some seasonal effects.

E.g., Arendas (2015) show that soybean market demonstrates strong seasonality: soybean prices tend to rise during May-July period and fall during October. This can be a signal of the Halloween effect's presence. The same may be true for tea market as well. For example, Induruwage et al. (2016) test black tea auction prices for seasonality in order to develop a better forecasting model. Results of econometric estimation show that there exist two month seasonal cycles between sampled tea auction prices.

Unlike previous studies of the Halloween effect on agricultural markets, we use up to date price series and the sample includes 27 major agricultural commodities. Also the "reverse Halloween effect" hypothesis is tested for sampled markets.

The purpose of this paper is to investigate the presence of the Halloween effect on sampled markets for agricultural commodities. In the case of confirmation of the hypothesis, the results obtained can be useful both to professional market players and regulators as well as to agribusiness subjects in part of risk hedging. Also, in case of confirmation of the hypothesis, we get additional confirmation of the weakness of the neoclassical efficient markets hypothesis.

\section{Materials and methods}

In this paper we investigate the presence of the Halloween effect on different markets for agricultural commodities for the period from 1980 to 2016. For the study we use monthly closing prices for bananas, barley, beef, coarse wool, cocoa, coffee Arabic, coffee Robusta, corn, cotton, fine wool, fish meal, hides, lamb, olive oil, oranges, palm oil, pork, poultry, rice, rubber, soybean, soybean meal, soybean oil, sugar, sunflower oil, tea and wheat. Data were provided by the International Monetary Fund (IMF) database.

To study the Halloween effect, following Arendas (2017), we divide each calendar year consisting of 12 months into two periods - winter and summer. In case of presence of the Halloween effect, the returns of the winter period should be significantly higher in comparison with the returns of the summer period. The end of summer and the beginning of the winter period will be around Halloween. In this study, a turning point from one period to another is the closing price 
of the last trading day in October.

Thus, definition of the turning point from the winter period to the summer period is ambivalent. In professional circles it is believed that it is necessary to "sell in May and go away". So, in most papers studying the Halloween effect, the turning point is determined as the last trading day of April. In this paper we use two alternative turning points: closing price of the last trading day in April and the closing price of the last trading day in May. This allows us to study several variations of the Halloween effect.

Such formulation of the problem allows us to propose and test the following hypotheses:

H1: The Halloween effect is present in the energy market.

H2: The observed cases of the Halloween effect are statistically significant.

H3: The returns in the sampled markets follow the similar patterns.

According to the Hypothesis H1, the Halloween effect can be observed on agricultural commodities markets. If the assumption of this hypothesis is correct, then the returns of the winter period (October-April or October-May) must be higher than the returns of the summer period (May-October or June-October). It is logical to assume that for the selected observation period (36 years) we can certainly find the years in which this assumption is incorrect. However, if the Halloween effect is present on the particular market for agricultural commodities, the number of years of its presence must be more than the number of years of its absence. The same is true for comparisons of average returns of summer and winter periods on 36 years' time span - average returns of summer period should be lower in comparison with the average returns of the winter period.

Hypothesis H2 assumes that the observed cases of the presence of the Halloween effect are statistically significant. Since the average results may be greatly skewed due to the years in which the markets showed abnormal levels of return, the difference between the returns of summer and winter period should be statistically significant to prove the presence of the Halloween effect on the market. Otherwise, this pattern can be considered as a random disturbance on the market caused by an exogenous shock.

Hypothesis H3 introduces the assumption under which the related markets should behave in a similar way. We assume that related markets are influenced by similar factors. And this leads to what should trigger the substitution effect, which in turn should generate similar anomalies on related markets. We expect to see similar patterns of behavior on the sampled markets. Out of 27 commodities, similar pattern may occur in following subgroups:

- Meats: beef, pork, poultry, lamb;

- Oils: palm oil, soybean oil/olive oil, sunflower oil;

- Soybean and soybean products: soybean, soybean oil, soybean meal;

- Coffees: coffee Arabica, coffee Robusta;

- Wools: coarse wool, fine wool;

- Cereals: barley, corn, rice, wheat

If the Halloween effect is present on a particular market, the average returns of the winter period should be considerably higher in comparison with the average summer returns. To test the hypotheses presented in this paper, we use parametric (Two-sample t-test) and nonparametric (Wilcoxon rank sum test) statistical tests to assess the statistical significance of the difference between the returns of summer and winter period for selected markets.

The Shapiro-Wilk test is used to determine which type of test, parametric or nonparametric, is more suitable to test a particular data. In our case, the Shapiro-Wilk test should show whether the returns come from a normally distributed population. Despite the fact that there is a large number of tests to determine the normality of distribution, Shapiro-Wilk test is considered to be one of the most accurate (Razali and Wah, 2011). A study conducted by Arendas (2017) also shows the possibility of its application to the study of the Halloween effect on selected markets. If returns come from a normally distributed population, it is more appropriate to use the Two-sample t-test. If the returns do not come from a normally distributed population, Wilcoxon rank sum test is more suitable. The use of this test allows to assess the statistical significance of the difference between returns of summer and winter periods.

Two-sample F-test is used to determine the identity of the variances for the returns of summer and winter periods. Depending on the result of the study, we will use Two-sample t-test for equal variances or Two-sample t-test for unequal variances. 
The algorithm of the research includes the following steps:

1. We calculate the return for particular markets on a certain time period. Each calendar year is divided into two periods: winter and summer. Given the differences in the definition of turning points, in the first case the calendar year is divided into periods from the last trading day of October to the last trading day of April of the following year (winter) and from the last trading day of April to the last trading day of October (summer period). In the second case, the summer period lasts from the last trading day of May to the last trading day in October and the winter period - from the last trading day of October through the last trading day of May. Monthly closing agricultural commodities prices from the database of the IMF are used.

The return is calculated by the following formulas:

$$
\begin{aligned}
& r_{s_{n}}=\frac{P_{o_{n}}-P_{A_{n}}}{P_{A_{n}}} \\
& r_{w_{n}}=\frac{P_{A_{n+1}}-P_{O_{n}}}{P_{o_{n}}}
\end{aligned}
$$

where: $r_{s_{n}}$ the return for the summer period, $r_{w_{n}}$ is the return for the winter period, $n$ represents the calendar year, $P_{O_{n}}$ is the October closing price for year $\mathrm{n}$ and $P_{A_{n}}$ is the April closing price for year n. For the second case, $P_{M_{n}}$ (May closing price for year n) and $P_{M_{n+1}}$ are used instead of $P_{A_{n}}$ and $P_{A_{n+1}}$ respectively.

2 . We calculate descriptive statistics. The descriptive statistics include the average returns for a specific time period, minimum and maximum returns, as well as the level of the presence of the Halloween effect (the number of years that the Halloween effect has emerged during the 36-year period).

3. To test whether the returns of a given period come from a normally distributed population, we use the Shapiro-Wilk test. Based on the obtained results, we decide whether to use Two-sample t-test or Wilcoxon rank sum test.

4. The Two-sample F-test for variances is used to determine whether the returns of winter and summer periods have equal variances. The result will determine the type of test most appropriate for the study: two sample t-test for equal variances or Two-sample t-test for unequal variances.

5. The Two-sample t-test is used to determine whether the difference between the returns of summer and winter periods for a particular commodity are statistically significant.
6. We use Wilcoxon rank sum test, due to its advantages over the Two-sample t-test for data that is not characterized by normal distribution.

7. We evaluate the validity of the hypotheses

\section{Results and discussion}

The results of the study show that the differences in returns in winter and summer periods in selected markets vary significantly. The same is true for the minimum and maximum returns on the markets. Strong difference may be found when comparing two different alternatives of the Halloween effect. If we turn to the percent of the presence of the Halloween effect, we could see that depending on the turning point and on the particular market, the percentage of its presence also varies significantly.

For the first alternative, where the summer period lasts from May to October and winter period - from November to April, most markets showed returns in winter period significantly higher than in the summer period (Table 1). In the first alternative, 20 out of the 27 sampled agricultural commodities show higher returns in the winter period that in the summer period. The largest differences (more than 12\%) are recorded for coffee Arabica, cotton, palm oil and soybean oil. The significant differences (more than 10\%) are also recorded for coarse wool, corn, oranges, rubber and soybean. At the same time beef, fish meal, hides, poultry, sugar, tea and wheat show higher average returns in summer periods than in winter periods. Out of these seven agricultural commodities, the largest difference is in cases of sugar and tea, where the average summer period returns are higher by more than $10 \%$.

As we have pointed out before, the level of presence of the Halloween effect varies significantly from one market to another. The Halloween effect can be mostly often observed on the markets for bananas, corn, cotton, olive oil, palm oil, soybean and soybean (more than $75 \%$ of cases). On the other hand, beef, coffee Robusta, fish meal, hides, poultry, sugar, tea and wheat experienced the Halloween effect in less than $50 \%$ of cases.

Regarding the second alternative, where the turning point is May, results are generally similar to the previous one. As in the first alternative, in most cases, the Halloween effect is present on 20 out of the 27 sampled markets, where average winter returns are higher than in the summer period. 


\begin{tabular}{|c|c|c|c|c|c|c|c|c|c|}
\hline \multicolumn{10}{|c|}{ Halloween effect (time span 1) } \\
\hline & \multicolumn{3}{|c|}{ Summer returns (May-October) } & \multicolumn{3}{|c|}{ Winter returns (November-April) } & \multicolumn{3}{|c|}{ Resulting statistics } \\
\hline & 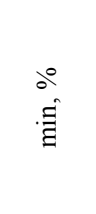 & 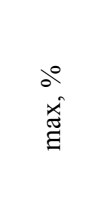 & 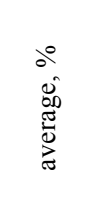 & 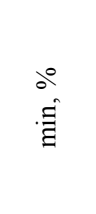 & 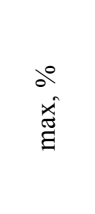 & 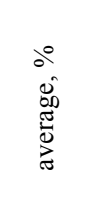 & 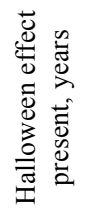 & 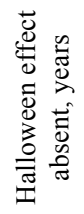 & 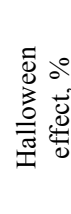 \\
\hline Bananas & -25.41 & 31.98 & 1.29 & -18.34 & 48.93 & 6.67 & 28 & 8 & 78 \\
\hline Barley & -41.25 & 32.15 & -1.13 & -23.16 & 31.59 & 4.82 & 21 & 15 & 58 \\
\hline Beef & -21.92 & 42.58 & 1.63 & -19.99 & 36.53 & 1.39 & 15 & 21 & 42 \\
\hline Coarse wool & -38.49 & 44.91 & -2.74 & -17.89 & 63.21 & 7.87 & 25 & 11 & 69 \\
\hline Cocoa & -25.42 & 43.74 & 0.88 & -29.12 & 46.72 & 1.91 & 19 & 17 & 53 \\
\hline Coffee Arabica & -51.87 & 124.32 & -3.01 & -40.38 & 78.44 & 9.14 & 23 & 13 & 64 \\
\hline Coffee Robusta & -43.26 & 131.49 & -0.57 & -32.97 & 70.19 & 6.28 & 14 & 22 & 39 \\
\hline Corn & -36.65 & 51.12 & -2.89 & -15.74 & 52.78 & 8.27 & 27 & 9 & 75 \\
\hline Cotton & -49.67 & 44.98 & -5.03 & -16.72 & 73.49 & 8.83 & 27 & 9 & 75 \\
\hline Fine wool & -42.84 & 38.65 & -3.65 & -35.97 & 64.91 & 10.35 & 22 & 14 & 61 \\
\hline Fish meal & -18.32 & 95.68 & 7.84 & -38.61 & 41.22 & 1.34 & 9 & 27 & 25 \\
\hline Hides & -35.61 & 86.25 & 4.67 & -59.65 & 36.81 & 1.79 & 17 & 19 & 47 \\
\hline Lamb & -45.87 & 78.39 & 3.34 & -23.49 & 95.12 & 6.72 & 23 & 13 & 64 \\
\hline Olive oil & -38.14 & 51.14 & -1.03 & -17.24 & 64.83 & 5.37 & 28 & 8 & 78 \\
\hline Oranges & -11.89 & 47.19 & -2.03 & -9.74 & 75.38 & 8.41 & 26 & 10 & 72 \\
\hline Palm oil & -57.38 & 61.42 & -4.49 & -34.50 & 56.29 & 9.97 & 28 & 8 & 78 \\
\hline Pork & -45.83 & 112.86 & 1.19 & -42.87 & 53.94 & 4.92 & 19 & 17 & 53 \\
\hline Poultry & -8.15 & 25.18 & 4.71 & -17.92 & 15.91 & -0.78 & 12 & 24 & 33 \\
\hline Rice & -41.19 & 34.13 & -1.23 & -32.38 & 189.64 & 4.64 & 19 & 17 & 53 \\
\hline Rubber & -33.05 & 47.24 & -2.86 & -20.24 & 69.13 & 7.16 & 23 & 13 & 64 \\
\hline Soybean & -48.13 & 45.82 & -4.28 & -13.11 & 34.18 & 6.73 & 27 & 9 & 75 \\
\hline Soybean meal & -60.81 & 58.08 & 0.84 & -28.19 & 41.14 & 4.72 & 20 & 16 & 56 \\
\hline Soybean oil & -42.71 & 60.13 & -4.16 & -24.39 & 48.85 & 8.70 & 27 & 9 & 75 \\
\hline Sugar & -43.56 & 94.57 & 8.83 & -57.04 & 67.93 & -2.16 & 15 & 21 & 42 \\
\hline Sunflower oil & -56.93 & 112.34 & -1.98 & -32.83 & 88.49 & 5.22 & 24 & 12 & 67 \\
\hline Tea & -78.94 & 43.12 & 9.25 & -27.78 & 93.56 & 1.17 & 12 & 24 & 33 \\
\hline Wheat & -35.98 & 72.44 & 5.84 & -29.05 & 25.82 & 0.82 & 19 & 17 & 53 \\
\hline
\end{tabular}

Source: own calculations

Table 1: Halloween effect statistics (alternative 1).

(Table 2) The largest differences are recorded for pork, coffee Arabica, fine wool and palm oil (more than 17\%). Out of 7 agricultural commodities with higher returns in the summer period than in winter, the largest difference is shown by tea, sugar and fish meal (more than 10\%).

The biggest success rate of the Halloween effect in alternative 2 (more than $70 \%$ ) can be seen in cases of bananas, olive oil, corn, palm oil, pork, soybean and soybean oil. The highest success rate is recorded for soybean $(83 \%)$. On the other hand, cocoa, fish meal, sugar and tea experienced the Halloween effect in less than $50 \%$ of cases.
If we compare the average level of the presence of the Halloween effect in the first and second alternatives, the first alternative average level of the Halloween effect presence is 59\%, and in the second alternative - $62 \%$.

Also, the difference between the average winter period and summer period returns is bigger in the second alternative than in the first one for most cases (Figure 1). 


\begin{tabular}{|c|c|c|c|c|c|c|c|c|c|}
\hline \multicolumn{10}{|c|}{ Halloween effect (time span 2) } \\
\hline & \multicolumn{3}{|c|}{ Summer returns (June-October) } & \multicolumn{3}{|c|}{ Winter returns (November-May) } & \multicolumn{3}{|c|}{ Resulting statistics } \\
\hline & $\begin{array}{l}{ }^{\circ} \\
\text { 䄪 }\end{array}$ & 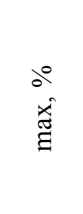 & 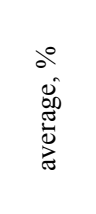 & $\begin{array}{l}\partial^{\circ} \\
\hat{\Xi} \\
\dot{a}\end{array}$ & 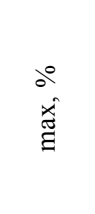 & 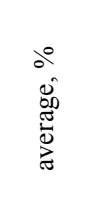 & 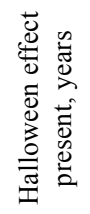 & 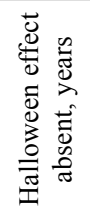 & 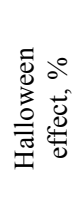 \\
\hline Bananas & -28.19 & 33.17 & 1.44 & -20.95 & 50.61 & 6.92 & 27 & 9 & 75 \\
\hline Barley & -14.87 & 40.80 & -2.95 & -12.48 & 34.58 & 8.18 & 23 & 13 & 64 \\
\hline Beef & -36.79 & 39.02 & 2.04 & -27.73 & 32.17 & 1.44 & 20 & 16 & 56 \\
\hline Coarse wool & -35.43 & 28.87 & -4.15 & -20.15 & 59.31 & 8.46 & 23 & 13 & 64 \\
\hline Cocoa & -24.28 & 39.73 & 1.86 & -37.61 & 49.84 & 2.23 & 16 & 20 & 44 \\
\hline Coffee Arabica & -58.72 & 64.97 & -5.03 & -35.07 & 107.45 & 14.01 & 21 & 15 & 58 \\
\hline Coffee Robusta & -43.96 & 81.20 & -2.21 & -29.84 & 86.09 & 6.82 & 20 & 16 & 56 \\
\hline Corn & -39.18 & 45.62 & -3.99 & -11.05 & 51.32 & 9.64 & 26 & 10 & 72 \\
\hline Cotton & -35.24 & 43.15 & -5.58 & -21.35 & 58.69 & 8.26 & 24 & 12 & 67 \\
\hline Fine wool & -41.99 & 26.83 & -5.93 & -27.01 & 69.03 & 12.19 & 25 & 11 & 69 \\
\hline Fish meal & -25.68 & 69.93 & 8.19 & -45.68 & 21.36 & 2.16 & 10 & 26 & 28 \\
\hline Hides & -32.46 & 77.04 & 3.65 & -57.38 & 39.06 & 2.94 & 20 & 16 & 56 \\
\hline Lamb & -29.09 & 82.47 & 4.08 & -31.14 & 54.10 & 7.03 & 22 & 14 & 61 \\
\hline Olive oil & -35.40 & 53.99 & 1.98 & -19.35 & 75.93 & 7.82 & 29 & 7 & 81 \\
\hline Oranges & -24.38 & 45.11 & -2.14 & 12.97 & 93.01 & 9.09 & 25 & 11 & 69 \\
\hline Palm oil & -57.88 & 56.81 & -5.26 & -37.04 & 81.14 & 12.04 & 27 & 9 & 75 \\
\hline Pork & -45.10 & 99.04 & -7.67 & -26.18 & 61.09 & 14.18 & 29 & 7 & 81 \\
\hline Poultry & -8.94 & 26.90 & 3.46 & -15.08 & 24.30 & 1.28 & 19 & 17 & 53 \\
\hline Rice & -40.52 & 41.18 & 1.02 & -36.41 & 203.48 & 3.90 & 19 & 17 & 53 \\
\hline Rubber & -38.87 & 40.36 & -2.94 & -19.77 & 53.08 & 7.83 & 25 & 11 & 69 \\
\hline Soybean & -46.05 & 37.14 & -6.72 & -16.70 & 38.06 & 10.24 & 30 & 6 & 83 \\
\hline Soybean meal & -49.84 & 51.22 & -1.67 & -31.42 & 44.57 & 6.98 & 25 & 11 & 69 \\
\hline Soybean oil & -37.51 & 57.84 & -4.84 & -28.05 & 61.32 & 9.16 & 27 & 9 & 75 \\
\hline Sugar & -37.14 & 81.25 & 8.03 & -66.70 & 59.03 & -2.92 & 14 & 22 & 39 \\
\hline Sunflower oil & -45.86 & 98.74 & -2.17 & -41.08 & 92.36 & 7.15 & 25 & 11 & 69 \\
\hline Tea & -62.41 & 32.18 & 10.16 & -31.05 & 103.25 & 1.49 & 13 & 23 & 36 \\
\hline Wheat & -32.99 & 75.39 & 5.93 & -26.12 & 34.58 & 0.48 & 21 & 15 & 58 \\
\hline
\end{tabular}

Source: own calculations

Table 2: Halloween effect statistics (alternative 2).

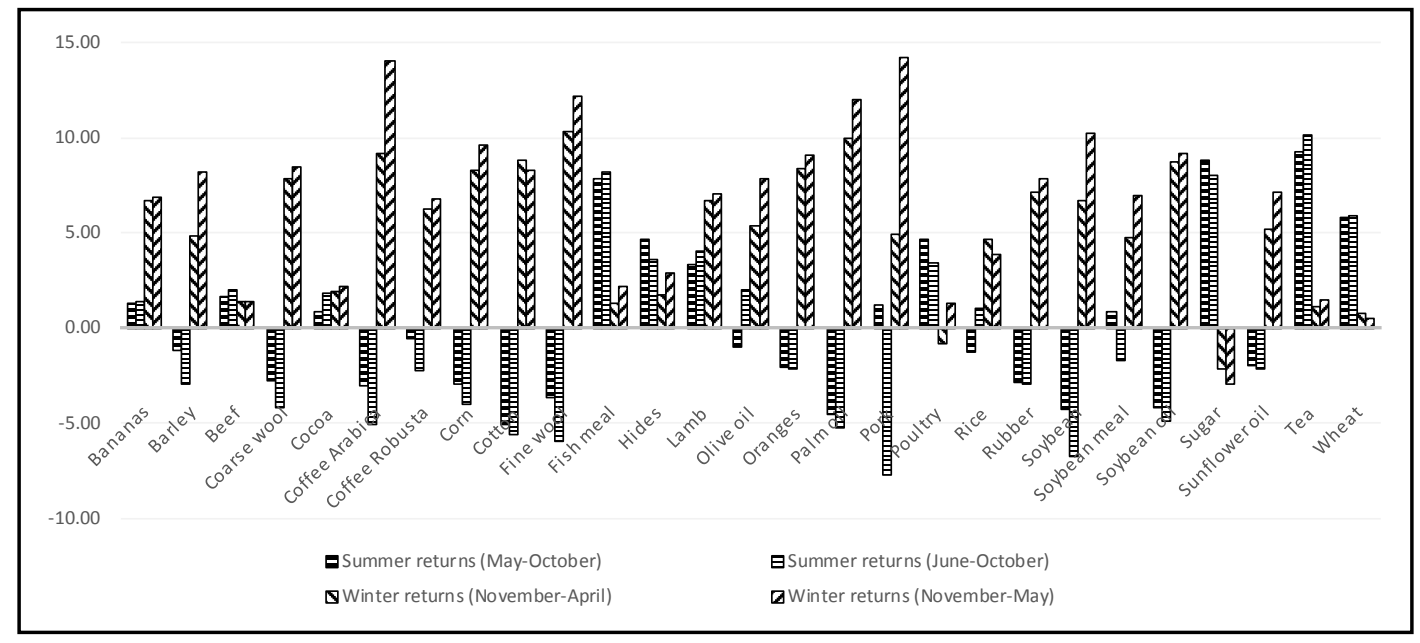

Source: own calculations

Figure 1: Average returns for sampled commodities. 
Table 3 presents the results of Two-sample t-test and Wilcoxon rank sum test. The cases in which the difference between returns in the summer and winter periods is statistically significant (at the significance level of 0.05) are highlighted. The cases in which a reverse Halloween effect manifested itself (when the returns of the summer periods are higher than returns in winter) are written in italics. Based on the results of Shapiro-Wilk test, we determined which test would be better suited for particular data sets: parametric Two-sample t-test or nonparametric Wilcoxon rank sum test. The results of a more appropriate test are in bold (Table 3).

As can be seen from Table 3, both test statistics are in agreement in all sampled markets for agricultural commodities, except coffee Arabica (alternative 1). In case of coffee Arabica, Two-sample t-test shows that the differences in returns between summer and winter periods are not statistically significant. In the same time, Wilcoxon rank sum test shows that the differences are statistically significant. Given that, the data sets are not normally distributed, the Wilcoxon rank sum test may be seen as a more appropriate test in this case. This allows us to assume that the Halloween effect is present on the market and statistically significant.

The results of the carried out research show that in case of both alternatives, the Halloween effect is present and statistically significant on the markets for bananas, coarse wool, coffee Arabica, corn, cotton, fine wool, lamb, olive oil, oranges, palm oil, soybean, soybean oil and sunflower oil. Only in the second alternative we can assume that the Halloween effect on the markets for barley and pork is statistically significant. The "reverse Halloween effect" is found on the markets for beef, fishmeal, hides, poultry, tea and wheat. Out of these

\begin{tabular}{|c|c|c|c|c|}
\hline \multirow{2}{*}{ Commodity } & \multicolumn{2}{|c|}{ Halloween effect (time span 1) } & \multicolumn{2}{|c|}{ Halloween effect (time span 2) } \\
\hline & two-sample $t$-test & Wilcoxon rank sum test & two-sample $t$-test & Wilcoxon rank sum test \\
\hline Bananas & 0.04562 & 0.00102 & 0.04359 & 0.00059 \\
\hline Barley & 0.08129 & 0.26804 & 0.01274 & 0.04641 \\
\hline Beef & 0.96204 & 0.91753 & 0.65302 & 0.89007 \\
\hline Coarse wool & 0.01035 & 0.01007 & 0.00328 & 0.00681 \\
\hline Cocoa & 0.65730 & 0.72406 & 0.93116 & 0.91305 \\
\hline Coffee Arabica & 0.12306 & 0.01994 & 0.02795 & 0.05603 \\
\hline Coffee Robusta & 0.47504 & 0.19502 & 0.09266 & 0.28509 \\
\hline Corn & 0.00396 & 0.00148 & 0.00743 & 0.00108 \\
\hline Cotton & 0.00701 & 0.01379 & 0.00312 & 0.01967 \\
\hline Fine wool & 0.00147 & 0.01486 & 0.00043 & 0.00214 \\
\hline Fish meal & 0.74908 & 0.64521 & 0.32159 & 0.25128 \\
\hline Hides & 0.90236 & 0.75306 & 0.64130 & 0.31117 \\
\hline Lamb & 0.00295 & 0.00172 & 0.00218 & 0.00113 \\
\hline Olive oil & 0.02274 & 0.03854 & 0.02135 & 0.03467 \\
\hline Oranges & 0.04582 & 0.03215 & 0.00249 & 0.00146 \\
\hline Palm oil & 0.00539 & 0.00413 & 0.00391 & 0.00056 \\
\hline Pork & 0.58402 & 0.29321 & 0.00107 & 0.00009 \\
\hline Poultry & 0.00184 & 0.00115 & 0.29539 & 0.35928 \\
\hline Rice & 0.45807 & 0.85403 & 0.71098 & 0.78051 \\
\hline Rubber & 0.06352 & 0.07297 & 0.04314 & 0.02173 \\
\hline Soybean & 0.00479 & 0.00218 & 0.00021 & 0.00024 \\
\hline Soybean meal & 0.52304 & 0.39506 & 0.08483 & 0.03480 \\
\hline Soybean oil & 0.01943 & 0.00512 & 0.00179 & 0.00054 \\
\hline Sugar & 0.24916 & 0.38627 & 0.23402 & 0.11396 \\
\hline Sunflower oil & 0.00941 & 0.03158 & 0.00489 & 0.02317 \\
\hline Tea & 0.96075 & 0.87142 & 0.59072 & 0.31134 \\
\hline Wheat & 0.52043 & 0.67421 & 0.78101 & 0.82773 \\
\hline
\end{tabular}

Source: own calculations 
markets only for poultry and tea market, the "reverse Halloween effect" is statistically significant.

Hypothesis H1, which suggests that the Halloween effect is present on the markets of the sampled agricultural commodities, can be accepted. Halloween effect is present on 20 out of the 27 markets for agricultural commodities. In these cases, average winter returns are higher than the returns in the summer periods. The results are true for both alternatives of the Halloween effect's sample. In case of 20 commodities (alternative 1) and 23 commodities (alternative 2), the success rate of the Halloween effect is more than $50 \%$ during the 36-year period. Based on these results we can conclude that the Halloween effect is present on the sampled markets for agricultural commodities for the period of 1980-2016.

Hypothesis H2, according to which the observed cases of the Halloween effect are statistically significant in nature, can be partially accepted. Even if not in all cases, the Halloween effect is statistically significant in nature (in some cases, the excess returns of the summer period over the winter period can be the consequence of an exogenous shock that produced the abnormal return). Nevertheless, for 12 commodities (alternative 1) and 15 commodities (alternative 2), the Halloween effect is present and is statistically significant. We were also able to identify two statistically significant cases of the reverse Halloween effect (for markets of poultry and tea).

Hypothesis H3 (Returns of the related commodities follow similar patterns) can be partially accepted. Although there are some exceptions, the related commodities tend to follow similar patterns in most of the cases. The "oils" subgroup (palm oil, soybean oil, olive oil, sunflower oil) and "wools" subgroup (coarse wool, fine wool) have similar patterns of behavior consistent with the Halloween effect, which are statistically significant. The "soybean and soybean products" subgroup as well as "coffees" subgroup also show the Halloween effect pattern. The "cereals" subgroup, which includes barley, corn, rice and wheat, show the following results: in cases of barley, corn and rice, the average winter periods returns are higher than the average summer period returns. The opposite is true for the wheat market. The "meats" subgroup show ambiguous results: cases of beef and poultry show higher average summer period returns, while pork and lamb show higher average winter period returns. As the data show, the related commodities behave similarly in most of the cases. Exceptions may be attributed to specifics of the production cycles or natural events, exogenous in nature.

Therefore, it is able to conclude that the Halloween effect is present on the markets for agricultural commodities. Its strength differs market to market, but in most cases it is strong enough to become a shibboleth for profitable strategies, which could generate abnormal returns even after taking the transaction costs into account.

Even given the fact that there is extensive research on the Halloween effect, consensus on the nature and sources of the Halloween effect doesn't exist. Hong and $\mathrm{Yu}$ (2009) attribute the Halloween effect to the summer holidays, when investors go on vacation and trading volumes on the exchanges are significantly reduced. Some authors consider that the Halloween effect's source lies in changes of weather, because the colds and decreasing temperature leads to an increase in aggression, and apathy (Cao and Wei, 2005). For this reason, winter returns tend to be higher, because market players are trading in a more aggressive manner. On the other hand, Jacobsen and Marquering (2008) presented evidence that the weather factor is hardly a Halloween effect's source on the stock market. On the other hand, even if this is true for the stock market, the weather definitely has an impact on the seasonality of trading on the markets of agricultural commodities (Arendas, 2017). E.g., Ott (2013) showed that the intra-year agricultural commodities price volatility is strongly affected by the stock-to-use ratio. Weather, therefore, significantly affects production cycles of different commodities and stock levels and need to be taken into account when dealing with price volatility on the markets for agricultural commodities

\section{Conclusion}

This study investigates the presence of the Halloween effect on the markets for agricultural commodities over the 36-year period. The sample of commodities consist of 27 major agricultural goods, including meats, cereals, oil, and soybean subgroups.

The results of testing the hypotheses, stated in this paper, show that the Halloween effect is present on the markets for agricultural commodities. 20 out of the 27 sampled commodities have higher average winter period returns that the average summer period returns and in half of the cases, the results are statistically significant. Also we've detected the statistically significant presence of the "reverse Halloween effect" on the markets for poultry and tea. 
The results of the study show that seasonality on a number of the agricultural commodities markets may generate excessive returns due to differences between summer and winter periods average returns. Such anomaly may be used by professional traders, agribusiness subjects for their purposes.

Corresponding authors:

Dr. Dmitry Burakov

Department of Financial Markets \& Banking

Financial University under the Government of Russian Federation

Leningradsky prospect 49, Moscow, 125993, Russia,

E-mail:dbur89@yandex.ru

\section{References}

[1] Andrade, S. C., Chhaochharia, V. and Fuerst, M. E. (2013) "“Sell in May and Go Away" Just Won't Go Away", Financial Analysts Journal, Vol. 69, No. 4, pp. 94-105. ISSN 0015-198X. DOI 10.2469/faj.v69.n4.4.

[2] Arendas, P. (2015) "The soybean market price cycle and its application on investment strategies", Nová Ekonomika, Vol. 8, No. 3, pp. 31-38.

[3] Arendas, P. (2017) "The Halloween effect on the agricultural commodities markets", Agricultural Economics, Vol. 63, No. 10, pp. 441-448. ISSN 0139-570X. DOI 10.17221/45/2016-AGRICECON.

[4] Borowski, K. (2015) "Analysis of selected seasonality effects in market of barley, canola, rough rice, soybean oil and soybean meal future contracts", Journal of Economics and Management, Vol. 21, pp. 73-89. ISSN 1732-1948.

[5] Bouman, S. and Jacobsen B. (2002) "The Halloween indicator, "sell in May and go away": Another puzzle", American Economic Review, Vol. 92, No. 5, pp. 1618-1635. ISSN 0002-8282. DOI 10.1257/000282802762024683.

[6] Burakov, D. (2017) "Oil Prices, Exchange Rate and Prices for Agricultural Commodities: Empirical Evidence from Russia”, AGRIS On-line Papers in Economics and Informatics, Vol. 8, No. 2, pp. 17-31. ISSN 1804-1930. DOI 10.7160/aol.2016.080203.

[7] Cao, M. and Wei, J. (2005) "Stock market returns: A note on temperature anomaly", Journal of Banking \& Finance, Vol. 29, No. 6, pp. 1559-1573. ISSN 0378-4266. DOI 10.1016/j.jbankfin.2004.06.028.

[8] Čermák, M., Malec, K. and Maitah, M. (2017) "Price Volatility Modelling - Wheat: GARCH Model Application", AGRIS on-line Papers in Economics and Informatics, Vol. 9, No. 4, pp. 15-24. ISSN 1804-1930. DOI 10.7160/aol.2017.090402.

[9] Etienne, X. L., Irwin, S. H. and Garcia, P. (2014) "Bubbles in food commodity markets: Four decades of evidence", Journal of International Money and Finance, Vol. 42, pp. 129-155. ISSN 0261-5606. DOI 10.1016/j.jimonfin.2013.08.008.

[10] Fama, E. (1965) "Random walks in stock market prices", Financial Analysts Journal, Vol. 51, No. 1, pp. 55-59. ISSN 0015-198X. DOI 10.2469/faj.v51.n1.1861.

[11] Haggard, K. S., Jones, J. S. and Witte, H. D. (2015) "Black cats or black swans? Outliers, seasonality in return distribution properties, and the Halloween effect”, Managerial Finance, Vol. 41, No. 7, pp. 642657. ISSN 0307-4358. DOI 10.1108/MF-07-2014-0190.

[12] Hamilton, J. D. and Wu, J. C. (2015) "Effects of index-fund investing on commodity futures prices", International Economic Review, Vol. 56, No. 1, pp. 187-205. ISSN 1468-2354. DOI 10.1111/iere.12099.

[13] Hochman, G., Rajagopal, D., Timilsina, G. and Zilberman, D. (2014) "Quantifying the causes of the global food commodity price crisis", Biomass and Bioenergy, Vol. 68, pp. 106-114. ISSN 0961-9534. DOI 10.1016/j.biombioe.2014.06.012. 
[14] Hong, H. and Yu, J. (2009) "Gone fishin': seasonality in trading activity and asset prices", Journal of Financial Markets, Vol. 12, No. 4, pp. 672-702. ISSN 1386-4181. DOI 10.1016/j.finmar.2009.06.001.

[15] Induruwage, D., Tilakaratne, C. D. and Rajapaksha, S.R.M.S.P. (2016) "Forecasting Black Tea Auction Prices by Capturing Common Seasonal Patterns", Sri Lankan Journal of Applied Statistics, Vol. 16, No. 3, pp. 195-214. ISSN 1391-4987. DOI 10.4038/sljastats.v16i3.7832.

[16] Jacobsen, B. and Marquering, W. (2008) "Is it the weather?", Journal of Banking \& Finance, Vol. 32, No. 4, pp. 526-540. ISSN 0378-4266. DOI 10.1016/j.jbankfin.2007.08.004.

[17] Jacobsen, B. and Nuttawat, V. (2009) "The Halloween effect in U.S. sectors", Financial Review, Vol. 44, No. 3, pp. 437-459. ISSN 1540-6288. DOI 10.1111/j.1540-6288.2009.00224.x.

[18] Lakonishok, J. and Smidt, S. (1988) "Are seasonal anomalies real? A ninety-year perspective", Review of Financial Studies, Vol. 1, No. 4, pp. 403-424. ISSN 1465-7368. DOI 10.1093/rfs/1.4.403.

[19] Lean, H. H. (2011) “The Halloween puzzle in selected Asian stock markets”, Journal of Economics and Management, Vol. 5, pp. 216-225. ISSN 1732-1948.

[20] Liu, L. (2014) "Cross-correlations between crude oil and agricultural commodity markets", Physica A: Statistical Mechanics and its Applications, Vol. 395, pp. 293-302. ISSN 0378-437. DOI 10.1016/j.physa.2013.10.021.

[21] Mensi, W., Hammoudeh, S., Nguyen, D. K. and Yoon, S.-M. (2014) "Dynamic spillovers among major energy and cereal commodity prices", Energy Economics, Vol. 43, pp. 225-243. ISSN 0140-9883. DOI 10.1016/j.eneco.2014.03.004.

[22] Milonas, N. T. (1991) "Measuring seasonalities in commodity markets and the half-month effect", The Journal of Futures Markets, Vol. 11, No. 3, pp. 331-345. ISSN 1096-9934. DOI 10.1002/fut.3990110307.

[23] Ott, H. (2013) "Extent and possible causes of intrayear agricultural commodity price volatility", Agricultural Economics, Vol. 45, No. 2-3, pp. 225-252. ISSN 1574-0862. DOI 10.1111/agec.12043.

[24] Razali, N. M. and Wah, Y. B. (2011) "Power comparison of Shapiro-Wilk, Kolmogorov-Smirnov, Lilliefors and Anderson-Darling tests", Journal of Statistical Modeling and Analytics, Vol. 2, pp. 21-33. ISBN 978-967-363-157-5.

[25] Wang, Y., Wu, C. and Yang, L. (2014) "Oil price shocks and agricultural commodity prices", Energy Economics, Vol. 44, pp. 22-35. ISSN 0140-9883. DOI 10.1016/j.eneco.2014.03.016.

[26] Zhang, C. Y. and Jacobsen, B. (2013) "Are monthly seasonals real? A three century perspective" Review of Finance, Vol.17, No. 5, pp. 1743-1785. ISSN 1573-692X. DOI 10.1093/rof/rfs035. 